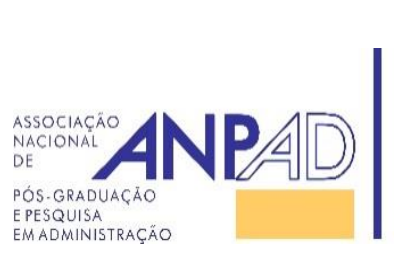

Available online at http://www.anpad.org.br/bar

BAR, Rio de Janeiro, v. 15, n. 2, art. 2, e170100, 2018

\title{
Taste Transformation in the Context of Social Mobility
}

Lucivania Filomeno Ponte ${ }^{1}$

Roberta Dias Campos ${ }^{2}$

Instituto Federal de Educação, Ciência e Tecnologia do Rio de Janeiro, Rio de Janeiro, RJ, Brazil ${ }^{1}$ Universidade Federal do Rio de Janeiro, Instituto COPPEAD de Administração, Rio de Janeiro, RJ, Brazil ${ }^{2}$

Received 12 August 2017; received in revised form 19 February 2018; accepted 12 March 2018; first published online 8 May 2018.

Editor's note. Valter Afonso Vieira served as Associate Editor for this article. 


\begin{abstract}
This article provides a theoretical effort to extend the literature on taste transformation and emphasize its shortcomings in explaining this process in social mobility contexts. Firstly, we conduct an overview of taste research in consumer behavior, followed by a presentation of the main concepts on taste transformation under debate in the literature of consumer culture theory and a discussion of the gaps in these frameworks. Secondly, we discuss how a context of social mobility could afford new directions for research on taste transformation. The Brazilian case is proposed as an illustration of this proposition due to its recent socioeconomic instability. Finally, we identify opportunities for future research by exploring (a) taste as a mechanism of distinction-across and (b) taste in inertial acquisition dynamics.
\end{abstract}

Key words: taste; taste transformation; new middle class; social mobility; culture and consumption. 


\section{Introduction}

Taste, an internal judge that consumers use to distinguish good from bad and right from wrong, has been widely discussed in social sciences (Bourdieu, 1984; Hennion, 2001; Warde, 1997) and consumer behavior (Allen, 2002; Hirschman \& Holbrook, 1982; Holt, 1998; Venkatesh, Joy, Sherry, \& Deschenes, 2010; Zeithaml, 1988). Recently, the topic has again gained traction in the realm of consumer culture to address issues related to movements of taste regime acquisitions (Arsel \& Bean, 2013; Maciel \& Wallendorf, 2017; Quintão, Brito, \& Belk, 2015; Skandalis, Banister, \& Byron, 2015).

The conceptualization of the taste construct, however, depends on the epistemological paradigm, which supports the viewpoints that define taste (Barcelos, 2015). Taste was presented by Bourdieu (1984) as a system of classification and distinction and as a mechanism for constructing social boundaries (Holt, 1998). Nevertheless, some studies (Venkatesh et al., 2010) distance themselves from this structural approach and emphasize, for instance, sensory aspects and psychological responses to aesthetic stimuli (Hirschman \& Holbrook, 1982; Holbrook, 2005), thus following a more individual approach to taste. Other researchers relate taste to socio-cultural issues and to social practices of consumption (Allen, 2002; Üstüner \& Holt, 2010).

This essay focuses on the approach of the Consumer Culture Theory (CCT) (Arnould \& Thompson, 2005) to investigate taste. This approach constitutes a fundamental construct for the understanding of consumer behavior and taste has recently amassed growing interest in the area. Subsequently, researchers are making every effort to understand the taste transformation processes, whether by developing a taste regime (Arsel \& Bean, 2013), analyzing taste transformation rituals (Quintão et al., 2015), or by studying the cultural competencies associated with the engineering of taste acquisition (Maciel \& Wallendorf, 2017).

Although these studies analyzed taste acquisition mechanisms, consumers, in the contexts studied, belonged to the same social class (Arsel \& Bean, 2013; Maciel \& Wallendorf, 2017; Quintão et al., 2015; Skandalis et al., 2015) with stable social position and without any ascension concerns or material constraints that could put them on a downward path in the societal structure. Those frameworks do not consider or explain taste dynamics in the vertical social mobility process, so the investigated consumers did not face new patterns of consumption previously unfamiliar to them.

In this sense, we may ask how taste transformation processes occur when consumers experience social mobility dynamics. This is precisely the case of consumers from the new middle class around the world, mainly represented by the BRIC economies (Kamakura \& Mazzon, 2013) and emergent markets like Turkey, India, and Eastern Europe (Kravets \& Sandikci, 2014). The recent growth of this social stratum in emerging countries (Kamakura \& Mazzon, 2013) became interesting contexts to investigate taste transformation phenomena, chiefly because of the occurrence of multiple and coexisting taste structures (Sandikci \& Ger, 2010).

Similarly, Brazil is a representative case of these dynamics due to its constant economic movements in the last decade. The Brazilian working class has experienced two movements, namely its ascent to the new middle class, in which individuals encounter new categories of products and brands (Mattoso, 2013; Neri, 2010; Rocha, Rocha, \& Rocha, 2016), and the return of budget constraints due to the country's political and economic instability (Pignata \& Carvalho, 2015). The Brazilian experience, as in other emerging economies, leads us to question the flatness of taste transformation constructs. In dynamic social mobility contexts, in which consumers experience a reformulation of their consumption learning parameters and references, could there be opportunities to conduct additional research on taste transformation? This question illustrates just one of the opportunities to investigate this theme in the realm of consumer behavior.

Following MacInnis' (2011) call for more conceptual thinking in our field, this article has two aims. The first aim is to address the debate around taste in consumer behavior and discuss contributions and remaining gaps in recent literature. The second goal is to display how the new middle-class 
phenomenon and social mobility environments are fostering the construction of a more complex approach to taste. In this sense, the consumption experience of the new Brazilian middle class is a promising laboratory for future research.

The paper begins with a review of taste literature. Then, we present the theoretical frameworks in the literature of the consumer culture theory used to analyze taste transformation. A third section examines the social mobility phenomenon and its articulation with contemporary thinking on taste transformation. Subsequently, we present the new Brazilian middle class as a promising research context. The last section discusses the limitations of current frameworks for analyzing taste transformation in a social mobility context. Finally, we identify opportunities for future research and outline potential contributions to (a) taste as a mechanism of distinction-across and (b) taste in inertial acquisition dynamics.

\section{The Taste Construct in Consumer Behavior}

In order to understand the role of taste in literature on consumer behavior, we performed a root metaphor analysis (Alvesson \& Sandberg, 2011) and outlined the different approaches to taste and their different theoretical bases. We identified that taste has been investigated according to three main different perspectives: (a) Taste as individual phenomena, (b) Taste as a social boundary, and (c) Taste as tension between structure and agency.

A significant stream of research envisions taste as an individual response to things. It may be, for instance, a synonym of judgment and the manifestation of preferences that become tangible with consumption objects. It also appears as an appropriate and consistent individual response to consumption objects, obtained through sensory means, or as an individual's emotional response to these objects (Zeithaml, 1988). Other studies analyze the sensory dimensions of taste related to the five senses of the individual (Bloch, 1995; Hirschman \& Holbrook, 1982; Venkatesh et al., 2010). Here, taste is seen as preferences that can be used to protect the consumer's identity project.

Another stream of research considers taste as a social boundary (Allen, 2002; Gronow, 1997; Holt, 1998; Pereira \& Ayrosa, 2012), which creates distinctions in a status game (Bourdieu, 1984; McQuarrie, Miller, \& Phillips, 2013; Üstüner \& Holt, 2010). In this approach, taste operates as a system of classification that perpetuates symbolic hierarchies through embodied action (Üstüner \& Holt, 2010). Taste theorization here draws on Bourdieu's definition of taste (1984) as a symptom of the habitus; the way he or she classifies himself or herself and classifies others. This view contrasts with the approach that considers taste as belonging to an individual dimension and pure individual aesthetic judgment. Accordingly, here taste is analyzed as an eminently social faculty resulting from class origin and education (Bourdieu, 2007; Holt, 2002) and manifested in embodied preferences, which focus on classbound resources such as education or long-term familiarity with artistic and aesthetic objects (Holt, 1998).

The last stream of research makes some advances in this viewpoint. According to this stream, in the postmodern condition, the consumer is supposed to be a liberated subject with agency (Firat \& Venkatesh, 1995) who assembles choices from marketplace resources through a process of bricolage. These studies reject a purely structural analysis in favor of a more contextualized interpretation perspective. Taste is investigated in terms of the affiliation of people, groups, or communities (Arsel \& Bean, 2013; Arsel \& Thompson, 2011) or as an aesthetic discrimination mechanism (Joy \& Sherry, 2003; McQuarrie et al., 2013). In this sense, taste, for this last stream of research, is the locus where the individual agency actively deals with a given structure.

Consequently, defining taste depends on the epistemological paradigm. The authors, following the consumer culture theory paradigm (Arnould \& Thompson, 2005), see taste as a social construction that involves not only its structural dimension but also the consumer's agency in the taste transformation 
process. Therefore, given the number of influential works that investigate taste, especially in the recent literature on consumer behavior (Arsel \& Bean, 2013; Maciel \& Wallendorf, 2017; Quintão et al., 2015; Skandalis et al., 2015), it is important to fully understand how taste is outlined in this more recent stream and how it is constructed or transformed in different consumption fields. The next section presents the different approaches used to discuss taste from a consumer culture perspective (Arnould \& Thompson, 2005) as a transformation process.

\section{The Taste Transformation Process}

The literature on taste transformation in consumer behavior, mainly in CCT articles, is inspired by sociocultural lenses. One important influence is the work of Bourdieu (1984), who conceives taste as a symptom of social distinction in a more structural manner. The second source of influence is Hennion (2001), who adopts a reflexive approach of taste as a dynamic activity expressed in daily consumption practices. In general, the Practice Theory is another pervasive theoretical lens in this research stream (Maciel \& Wallendorf, 2017), thus providing ground for an approach to taste that accommodates agency and structure (Askegaard \& Linnet, 2011). Other approaches to taste transformation emphasize the role of rituals (Quintão et al., 2015), while other studies throw light on the spatial dimensions of consumption (Skandalis et al., 2015). Some key sociocultural contributions and recent studies in consumer behavior are presented below.

Bourdieu's (1984) main contribution was to position taste as a process of elite domination and power (Woodward \& Emmison, 2001) that aims to produce cultural and social distinction. Thus, taste is shaped by the possession and display of different types of capital (economic, social and cultural), which manifest themselves through the habitus, and represents a generic set of schemas, resources and preferences that function as a key mechanism in explaining why and how individuals engage in a particular practice in their lives (Holt, 1998).

The concept of habitus provided some insight into the construction of identity and taste transformation (Arsel \& Bean, 2013; Skandalis et al., 2015) in the consumption field, as well as in the investigation of the reproduction of socio-cultural distinctions and identity in specific markets (Arnould \& Thompson, 2005). However, this approach analyzes the structural aspect of taste and is linked to the individual's primary socialization (Coskuner-Balli \& Thompson, 2013), without considering how taste is transformed in a subsequent moment and as a performance in different fields of consumption. Bourdieu's own study (Bourdieu \& Wacquant, 1992) argues that a field's specific capital is not acquired only during primary socialization, but also through participation in different social fields throughout life (Misoczky, 2003). Thus, habitus is continually developing as consumers engage in a specific consumption field (Skandalis et al., 2015).

Studies on consumer groups explore taste transformation processes in adulthood using a field theory framework, and associate consumption practices with the participation of consumers as members of communities whose practices are orchestrated by a discourse that is specific to these groups (Arsel \& Bean, 2013). Analogously, some studies analyze taste as a status consumption tool in the case of consumers of specific social classes (Arsel \& Thompson, 2011; Ponte \& Mattoso, 2014; Rocha et al., 2016; Üstüner \& Holt, 2010; Üstüner \& Thompson, 2012).

Rejecting this more structural approach, some authors such as Crossley (2001) affirm that Bourdieu's field theory and the notion of habitus are flawed because they do not consider the agency of individuals who, through their actions and interactions, could form and transform their habitus. Thus, whereas Bourdieu's concept of cultural capital sees taste as part of a static social arrangement, Gronow (1997) discusses taste from a dynamic perspective in a context of transitory patterns. Similarly, Hennion (2004) also questions the idea of taste in a passive and static social context and views taste as a reflexive activity rather than merely a given attribute. In other words, it is rather the result of a person's performance based on body training, comparison and repeated experiences that are gradually adjusted 
(Hennion, 2004). Thus, it is a matter of routine, practice, and habitual knowledge and it has a material effect on consumption (Allen, 2002; Shove, 2003; Warde, 1997).

The Practice Theory also offers tools to understand consumption patterns (Shove, 2003) and the transformation of consumption fields (Magaudda, 2011). Moreover, the association between taste and the Practice Theory allows researchers to understand how taste and the social structure operate in daily life, thus creating meanings. Social life is framed as an articulated and incorporated nexus of understandings, procedures, and engagements in which body and mind are key actors (Warde, 1997). The four most relevant papers on taste based on the approach of the Consumer Culture Theory that specifically investigate the taste transformation process are those of Arsel and Bean (2013), Quintão, Brito and Belk (2015), Skandalis, Banister and Byron (2015), and Maciel and Wallendorf (2017). A deeper account of these studies is provided below.

Arsel and Bean (2013) develop a framework of taste regimes to understand how discursive systems normalize a consumption practice in a specific field. This discourse aligns understandings, doings, objects, and meanings associated with consumption. Furthermore, a taste regime assumes there is an engagement on the part of the consumer to enter into a specific taste regime and, subsequently, to stay in this regime in a constant circuit of practice (Magaudda, 2011). Institutional information sources reveal consumers transform their dispersive practices, i.e. non-context related practices, into integrated ones, aligned with a specific regime, through ritualization and instrumentalization processes. Thus, consumers are constantly asking themselves what and how they should consume and make an effort to adjust to their practices with what is normalized by the particular discursive system of this taste regime.

Similarly, Maciel and Wallendorf (2017) propose the concept of taste engineering based on a field research on artisanal beer consumption experts, much like the study on coffee connoisseurs conducted by Quintão et al. (2015). The study broadens the understanding of cultural competence, i.e. the connection between objects, doings, and meanings in consumption practices (Arsel \& Bean, 2013; Belk, Wallendorf, Sherry, \& Holbrook, 1991; Hennion, 2004). However, Maciel and Wallendorf (2017) stress the role of corporeality, sensoriality, and feelings that were not investigated by previous studies.

The taste engineering framework positions learning practices as a process through which cultural competence, in the social structure, is constructed, leading to the transformation of individuals' sensitivities and understandings within the constraints of their habitus (Maciel \& Wallendorf, 2017). The aim of attaining a specific cultural competence depends on two resources: (a) a taste regime, which institutionally orchestrates objects, meanings, and doings and (b) a set of tools consisting of consumers' axiological and epistemological dispositions, which refer to their aesthetic values and preferred ways of acquiring knowledge according to their habitus. Taste engineering is a strategy of action fashioned with three tangled and dispersed practices (institutional benchmarking, autodidacticism, and cooperative scaffolding) through which consumers muddle together the body techniques, perceptions, and sayings of an integrative practice (Reckwitz, 2002; Schatzki 1996; Warde, 2005) to develop mastery or cultural competence in a social domain.

Additionally, consumer behavior studies tend to focus on identity issues and taste practices without considering the space in which taste is transformed (Skandalis et al., 2015). This is precisely the gap filled by the Spatial Theory of Taste Formation (Skandalis et al., 2015). Previous studies placed more emphasis on the analysis of practices and the results associated with taste than on understanding taste formation and the performance of consumers in consumption environments, as well as their identity projects within a socio-cultural framework.

A spatial theory of taste (Skandalis et al., 2015) allows the positioning of consumer's identity projects through taste formation in a framework based on Bourdieu's (1984) field theory concept. In other words, it recognizes that field participants make a constant effort to impose competition and belonging criteria, thus creating field limits (Bourdieu \& Wacquant, 1992; Misoczky, 2003). In this sense, each field prescribes its particular values and has its own regulatory principles, which contributes to the conservation or transformation of the structure (Misoczky, 2003). Consequently, the framework 
builds a bridge between taste and aesthetic experience with the potential to explore how consumers construct their identities through participation and experiences in a specific consumption field.

This is important because studies of consumption have not explained how habitus and taste are related to aesthetic experiences that emerge in different fields of consumption. The spatial theory has two aims. The first is to analyze how consumer taste is formed in contemporary consumption fields through engagement aesthetically oriented towards experiences. The second is to describe how the meanings associated with a specific place of consumption shape the consumer's consumption experiences and taste (Skandalis et al., 2015). The spatial theory specifically emphasizes the meanings of culturally incorporated places of consumption, but it is still important to clarify how the taste transformation process occurs in consumption spaces.

In CCT, theories associated with the consumption ritual have already been extensively discussed and they define constructs, cultural meanings, practices, and differentiation in the practice of the consumption ritual (McCracken, 1986; Rook, 1985; Schouten \& McAlexander, 1995; Sherry, 1983). Arsel and Bean (2013) drew on Rook's (1985) study to describe the ritualization of taste regimes. Ritual can be defined as an opportunity to affirm, evoke, attribute, or review the conventional symbols and meanings of the cultural order (McCracken, 1986). Rook (1985), however, describes ritual as a type of expressive and symbolic activity constructed according to multiple behaviors occurring in a fixed sequence of episodes that tend to repeat themselves over time. Along these lines, Quintão et al. (2015) broaden these definitions by introducing the concept of taste transformation ritual, which explains how people develop tastes through ritualistic consumption in relation to a specific product category. Contradicting Arsel and Bean (2013), who focus on how individuals convert taste into practice, Quintão et al. (2015) affirm that practice helps convert the taste of individuals through ritualization.

Taste transformation rituals allow consumers to make comparisons between tastes expressed in mass and expert consumption practices and develop their own consumption strategies. In this respect, the authors propose seven elements: (a) variation in choices of high-quality products; (b) the place where the performance of taste happens; (c) tasting moments; (d) tasting acts; (e) investment of time and money; (f) growth of social and subcultural types of capital; and (g) perseverance in rites of passage.

These four frameworks have a common start point: the individual's background constructed in their primary socialization. According to Bourdieu (1984), consumer's taste is, at first, shaped through acquiring capital and developing habitus in a field of consumption. Therefore, the current discussion is about how this taste is transformed throughout life. The four studies outline different ways to answer this question and all of them deal with the duality structure-agency to build their frameworks. Figure 1 shows the main elements of the processes designed by the authors.

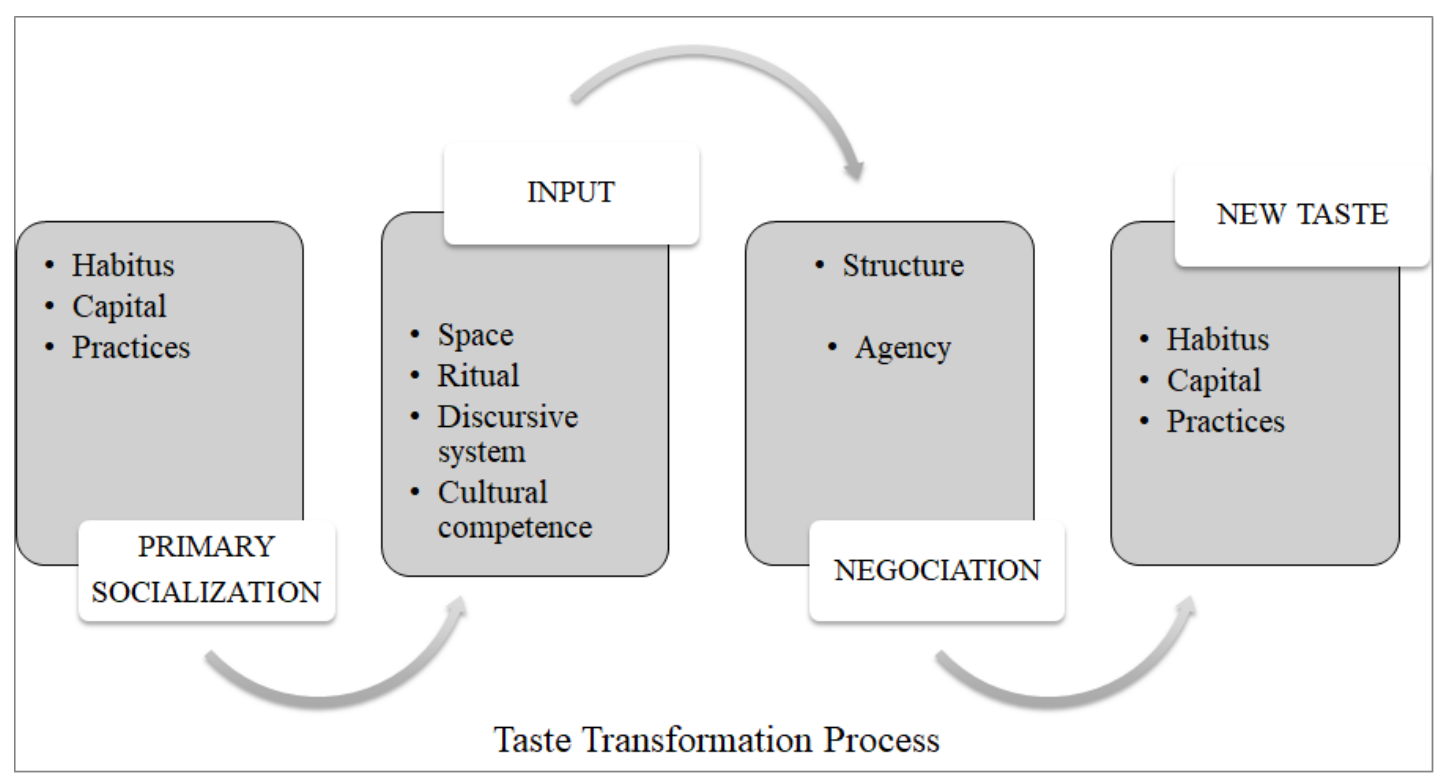

Figure 1. Taste Transformation Process in Consumer Behavior Literature 
The taste regime framework focuses on discursive systems as an input to the early process of taste transforming. It assumes consumers recognize this system and seek information to adapt to it, demonstrating a greater strength of the agency than the structure in this negotiation. Quintão et al. (2015) address the rituals as a start point by electing seven steps for the transformation process. This is also a consumer's strategic decision that gradually shapes consumer sensitivity. This proposal also places the agency as a stronger force in the negotiation between consumers and structure. Skandalis et al. (2015) stress the role of structure in shaping taste and build a contribution based on Bourdieu's (1984) field theory concept. In other words, they place the field as a central element of the taste transformation process. The spatial theory considers that consumers make a constant effort to align their taste to the field. Likewise, Maciel and Wallendorf (2017) highlight cultural competence as a starting point of taste transformation and argue for a greater weight of the agency on the structure in this negotiation.

All the studies investigated consumers who were in a stable socioeconomic position. Based on Bourdieu (1984), the authors investigated changes in cultural capital and emphasized soft changes in social capital, but none of them considered changes in economic capital and all the possible outcomes, even in social and cultural capital. Therefore, the social mobility context should be viewed as a new angle to theorize the taste transformation process.

\section{The Transformation of Taste in the Social Mobility Process}

The concept of social class founded on a classification of occupation and education was developed by sociologists and is used mainly in European markers (Kamakura \& Mazzon, 2013) in a context of low social mobility. Similarly, a very clear and stable classification is used in the United States: upper class, upper middle class, middle class, working class, and lower class (Beeghley, 2004). In these contexts, the process of taste transformation occurs within the same class and the frameworks previously presented explain this process very well. However, in emergent markets, the radical economic and cultural changes of the last years have muddled the traditional class descriptors (Kravets \& Sandikci, 2014). Similarly, in late capitalist societies, social status and economic power of the middle classes have become more volatile (Ulver \& Ostberg, 2014), causing social ascension and decline and the consequent transition of the consumers' social status, which is more recurrent in contemporary consumer culture.

Thus, the recent growth of the new middle class in emerging countries (Kamakura \& Mazzon, 2013) is a context that can be used to investigate taste transformation dynamics, mainly because of the multiple coexisting taste structures (Castilhos, Fonseca, \& Bavaresco, 2017; Sandikci \& Ger, 2010), since social boundaries are in flux and being negotiated (Kravets \& Sandikci, 2014).

Nevertheless, in consumer research, several works (Holt \& Thompson, 2004; McQuarrie et al., 2013) have investigated how taste is implicated in the reproduction of class and structure consumption (Kravets \& Sandikci, 2014). Researchers in this area have shown how people use consumption to construct identity (Belk, 1988; Thompson \& Hirschman, 1995) and demarcate their social position through status (Coskuner-Balli \& Thompson, 2013; Üstüner \& Holt, 2010) or even during transitional moments in their lives as consumers (Schouten, 1991). However, the economic and political environments create situations in which consumers find themselves in a state of constant movement, i.e. becoming something new instead of simply being (Ulver \& Ostberg, 2014). This calls for an investigation on the transformation of taste during the process of social movement. Studies mentioned so far mainly examine horizontal angles of taste of lateral mobility, i.e. they investigate less vertical mobility between classes. The exception is the article by Ulver and Ostberg (2014) which analyzes middle-class consumers who experienced a decline in social status. However, this study does not investigate taste transformation mechanisms.

In this dynamic context, taste fluctuates as a result of the performance of a person based on body training, comparison, and repeated experiences (Hennion, 2004), which function as mediators between the consumption object and culture through rituals (Quintão et al., 2015). Thus, to understand how the 
taste transformation process works, we must understand: (a) consumption objects, the variety of quality available to consumers (Arsel \& Bean, 2013; Maciel \& Wallendorf, 2017); (b) the space where consumption is performed (Skandalis et al., 2015); (c) the moment of use or tasting of the product (Quintão et al., 2015); (d) the time and money spent on consumption (Quintão et al., 2015); and (e) the increase in social and subcultural types of capital (Quintão et al., 2015). However, it is still imperative to describe the taste transformation process when it occurs in a consumer group during the transition in the social structure. Although two of the studies presented exhibit frameworks that provide a very good description of the taste transformation mechanisms - Taste Regimes (Arsel \& Bean, 2013) and Taste Engineering (Maciel \& Wallendorf, 2017) - they still have limitations in terms of investigating this phenomenon in a context of social mobility.

Brazil is a relevant case for this investigation of taste because it has faced two moments of robust social mobility. The economic growth in Brazil between 2003 and 2009, triggered mainly by income distribution (Kamakura \& Mazzon, 2013) and the consequent ascent of a lower social group to the new middle class, produced new consumption categories and the first taste transformation process. The second, more contemporary moment, led to budget constraints due to the current political and economic crisis and a new social decline, which will likely generate adaptations in consumer taste.

\section{The New Middle-Class Phenomenon: Brazilian Context of Social Mobility}

The term "new middle class" was first used in the 1950s (Mills, 1951, p. 191) to define a new social stratum that differed from the traditional middle class, symbolized by shop owners, small entrepreneurs, and farmers (Kravets \& Sandikci, 2014). The new middle class (NMC) phenomenon has been the subject of interest of anthropologists since the 1990s (Appadurai, 1996). It has also become a relevant context for marketing research since its emergence in the BRICS (Brazil, Russia, China, South Africa) when this group of countries experienced a vigorous growth from 1995 to 2010 (Kamakura \& Mazzon, 2013). It fashioned a hunger for consumption and helped reduce poverty in these countries. Geographically, research on the NMC extends from Brazil to Turkey and includes Eastern Europe and India. Although literature on the NMCs varies depending on the location, researchers point out similarities in the representational profile of this group (Kravets \& Sandikci, 2014).

The rise of this NMC is viewed as the driving force for economic growth because consumers adopt goods and services associated with a higher social status, causing the growth of internal demand (Kamakura \& Mazzon, 2013). Although the rise of the NMC always derives from macroeconomic changes, it causes shifts in many other dimensions, such as the increase in cultural capital, through access to education, and social capital, through the participation new social groups. The habitus of the NMC is configured not only from the incorporated class condition (Bourdieu, 1984) but also from the new practices of everyday life (Hennion, 2004). Therefore, the proliferation of various cultural meanings associated with consumption and the fragmentation of identity units have weakened this correspondence between social categories and consumption patterns (Holt, 1998).

In Brazil, there are two measures for defining the economic class. The first standard is the Brazilian economic classification criterion (Critério de Classificação Econômica Brasil [CCEB] or the Critério Brasil) that uses a household sample survey called Pnad (Pesquisa Nacional por Amostra de Domicílios), conducted by the Instituto Brasileiro de Geografia e Estatística (IBGE, n.d.). The second is based on the Getúlio Vargas Foundation (FGV) - and its concept of class stratification. To measure household purchasing power, the first criteria (CCEB) uses characteristics such as possession of assets, level of education of the head of a family, and the existence of employees in the household. It divides the population into five classes: A, B, C, D and E. Some authors (Chauvel \& Mattos, 2008; Neri, 2010), however, stress the deficiencies and limitations of the methodology used by the Critério Brasil (Mattar, 1997). In addition, the usage of possession of assets as a proxy of purchasing power is a fragile solution that easily becomes obsolete. With the increase in income and credit, goods have become more widespread and do not establish distinctions as they did previously (Jannuzzi, 2005). 
The Brazilian social structure underwent changes over relatively short periods, which eventually transformed the very definition of strata (Kamakura \& Mazzon, 2016). Between 2002 and 2009, the share of Class $\mathrm{C}$ - or the new Brazilian middle class - increased from $45.4 \%$ to $54.2 \%$. Class D, which, in 2002 , accounted for $15.5 \%$ of the population, fell to $12.2 \%$ in 2009 . Finally, the share of Class E declined sharply, shrinking from $26.1 \%$ in 2002 to $16.5 \%$ in 2009 (Neri, 2010). This represents a significant improvement in income distribution, with the share of lower-income groups declining and middle and higher income groups increasing (Scalon \& Salata, 2012). Among other factors, this movement was the result of income transfer programs, stable inflation, and the expansion of credit, which increased the earnings and consumption standards of many households (Barros, Carvalho, Franco, \& Mendonça, 2010). Consequently, many new consumers entered the market and encountered new consumption possibilities for the first time. There was also an increase in higher education (Kamakura \& Mazzon, 2013). In other words, consumers who had previously been obliged to make choices based on their livelihood, now had access to new categories of consumption, new services, and new types of choices, triggering a taste transformation process. Similarly, changes in their economic capital could also lead to changes in their cultural capital and social capital during the process of transformation.

Moreover, the social changes shaped their habitus and could also change their cultural and social capital from the change of economic capital built through social mobility.

Unfortunately, the economic factors that contributed to the rise of this new group of consumers, namely economic growth, low inflation rates, full employment, abundant credit, have been deteriorating swiftly since 2013 (Castilhos et al., 2017). Brazil also faces a serious political crisis with direct effects on the country's economy (Pignata \& Carvalho, 2015). Due to this economic fragility and restrictions on income distribution policies, the purchasing power of the NMC has been declining. A study published by the Getulio Vargas Foundation (Instituto Brasileiro de Economia da Fundação Getulio Vargas, 2014) revealed that the $\mathrm{A}, \mathrm{B}$ and $\mathrm{C}$ classes suffered a greater blow from the world economic crisis than in previous years. The NMC, which accounts for $52 \%$ of the population, is making an effort to maintain its consumption standards despite being affected by the crisis. Similarly, a survey conducted by Ibope (2015) showed that the NMC, composed of nearly 98 million people, is not willing to give up its standard of life and consumption. The survey revealed that this group resists making household budget reductions and is prepared to start shopping again at the first opportunity. Once again, these consumers will probably be engaged in new processes of taste transformation.

It is precisely this social roller coaster lived by the new Brazilian middle class that makes this stratum a rich illustration of the potential to investigate taste transformation under social mobility dynamics. It is not only merely an isolated phenomenon of class ascension or social decline; it is a continuous process of change and adaptation involving economic, social and cultural resources to rearrange habitus through a body training in everyday life in an incessant process of taste transformation.

\section{Final Considerations}

In order to investigate how changes in consumption patterns and associated taste transformation are processed in a social mobility context, such as the one experienced by Brazil's new middle class, this article presented the debate on taste in the realm of consumer behavior. As a result, the theme clearly offers research opportunities and generates a spirited discussion in the field, especially regarding the taste construction process.

Some studies investigate how individuals construct a complex system to participate in a tastebased status game (Arsel \& Thompson, 2011; Kates, 2002; McQuarrie et al., 2013; Üstüner \& Holt, 2010); however, they do not consider how the process involving the transformation of the consumer's evaluation systems begins. Other studies are still tied to the notion of habitus, associated with a specific social class, to explain taste (Bourdieu, 1984; Holt, 1998). But how does the taste transformation process occur when the consumer is involved in a social mobility process? 
As regards the frameworks presented (Arsel \& Bean, 2013; Maciel \& Wallendorf, 2017; Quintão et al., 2015; Skandalis et al., 2015), some provide a detailed description of the taste transformation process which may include the characteristics of the consumption space (Skandalis et al., 2015), highlight the importance of rituals associated with consumption and how they form consumer taste (Quintão et al., 2015), and focus on the discursively constructed normative system (Arsel \& Bean, 2013) that operates in consumption fields or the consumer's engagement in acquiring cultural competencies (Maciel \& Wallendorf, 2017) to hone in on their taste. However, as described above, the studies mentioned do not consider vertical social mobility in their analyses and are restricted to examining individuals and groups in a stable socio-economic position.

It is precisely because of this gap that the frameworks presented are unable to fully explain taste transformation dynamics of the new middle class. It also does not explain this process when it occurs in a more dynamic context like Brazil, which has gone through two distinct social mobility movements; one involving ascension and the second - still ongoing - involving decline, when economic factors have contributed to the rise of this new group of consumers (Castilhos et al., 2017). Thus, the question still remains - how does the taste transformation process occur when consumers experience these social mobility moments?

Two factors that are central to this discussion have not been examined in current studies, thus providing opportunities for future research: (a) Taste as distinction-across and (b) Taste in inertial acquisition dynamics. A more detailed analysis of these elements may provide inspiration for future investigations into the transformation of the tastes of groups involved in a social mobility process.

\section{Taste as distinction-across}

Arsel and Thompson (2011) demonstrate how consumers calibrate their tastes to a community or group to which they belong by identifying and sharing the field's dominant taste regime (Arsel \& Bean, 2013). Therefore, taste may serve as an instrument of affiliation (Gronow, 1997) or as a pattern of distinction (Bourdieu, 1984). Subsequently, Arsel and Bean (2013) coined the terms "taste as distinction-between" and "taste as distinction-over" (p. 139) other groups. The first refers to taste as a tool for the construction of limits and the formation of groups, reinforcing the process of belonging and association with a group and its particular taste regime. The second one is related to the preferences and claims of status and distinction relative to other groups, thus creating a classificatory hierarchy between groups (Bourdieu, 1984; Holt, 1998; McQuarrie et al., 2013). In all cases, however, it is a construction of taste - whether within or between groups - that dialogues with a reasonably stable classificatory social structure.

The studies by Arsel and Bean (2013) and Maciel and Wallendorf (2017) illustrate the dynamics of taste regime acquisition related to belonging to particular groups, such as artisanal beer drinkers. However, these groups only go through horizontal transitions, while maintaining their social status within the social group to which they belong. Quintão et al. (2015) and Skandalis et al. (2015) introduce the ritual and consumption space dimensions, but their analyses are also based on the assumption that the investigated group is socio-economically stable.

Nevertheless, the question is how to analyze the transformation of taste in the context of a vertical social mobility process, which may even, to a certain extent, destabilize the social classification structures themselves. As mentioned above, Brazil's new middle class has undergone two social mobility processes characterized by particular taste transitions and transformation dynamics. This mobility has made its own classification a complex matter. How then can we understand the discursive systems that operate in the transformation of consumer taste during the mobility process? Are they moving toward a specific taste regime or are they moving away from it? Are they building bridges and articulations between two different regimes? Or are they reformulating distinction parameters and the associated taste regimes? To answer these questions, future studies could investigate taste, as proposed here, in terms of distinction-across dynamics, i.e. how taste is transformed during the vertical social 
mobility process in which groups navigate in a classification system which is also undergoing a reformulation process (Ulver \& Ostberg, 2014).

\section{Taste in inertial acquisition dynamics}

Existing studies of taste transformation analyze situations where consumers purposefully engage in aesthetic competency and regime acquisition activities (Arsel \& Bean, 2013; Maciel \& Wallendorf, 2017). However, there are situations in which consumers may be confronted with new taste regimes that they do not understand or share, but end up learning inertially. This may occur through new lifestyle arrangements, resetting their social network, and exposure to unsought contents or possibilities, which lead consumers to gradually learn new consumption patterns.

According to the life course theory (Moreira, Casotti, \& Campos, 2018), individuals, in the course of their life trajectories, may experience changes in their social roles, consumption learning, and social interaction dynamics. In this way, consumers may be confronted with new categories of consumption, governed by yet unknown taste patterns. These consumers may not choose to actively acquire the necessary cultural competencies and absorb this system in a more inertial and less active fashion. The acquisition of new taste regimes may also be due to modifications in the patterns of influence individuals are subjected to during their socialization process (Ekström, 2006), when, for example, parents adopt new parental styles (Carlson \& Grossbart, 1988) or the mass media are challenged by new communication forms that pulverize and democratize access to information (McQuarrie et al., 2013).

Faced with a new consumption experience, the individual may resist entering a new taste regime and may be naturally unwilling to acquire the new cultural competencies (Maciel \& Wallendorf, 2017) associated with the regime. Here, the question is what are the processes through which taste is transformed if it is not conducted by the intentional incorporation of competencies? Social mobility situations provide an opportunity to study the commonly found dynamics of taste transformation, characterized by an inertial and unintentional acquisition, which does not constitute a conscious identity project (Arnould \& Thompson, 2005).

\section{Research agenda}

This article ends by proposing an agenda of research into taste transformation during the process of social mobility. Table 1 presents some research questions on three possible topics for future studies.

\section{Table 1}

\section{Research Agenda}

\begin{tabular}{ll}
\hline \multicolumn{1}{c}{ Topic } & \multicolumn{1}{c}{ Research question } \\
\hline Distinction-across & How do consumers adjust their taste references in new consumption \\
environments? & How does the practice of consuming new categories reframe taste \\
& regimes? \\
& How does the experience of integrating a new social class determine new \\
& taste engineering procedures? \\
& How does the experience of integrating a new social class, without the \\
& resource to a class habitus, define how consumers interact with a new taste \\
& regime? \\
& How does the absence of a previous class habitus make it harder to \\
& engineer one's taste? \\
\hline
\end{tabular}


Table 1 (continued)

\begin{tabular}{|c|c|}
\hline Topic & Research question \\
\hline \multirow[t]{3}{*}{ Inertial taste acquisition } & How do consumers incorporate new taste regimes initially? \\
\hline & $\begin{array}{l}\text { How does taste transformation operate when consumers do not drive the } \\
\text { cultural competence acquisition? }\end{array}$ \\
\hline & $\begin{array}{l}\text { How does a taste regime incorporation happen when it is felt as being } \\
\text { imposed on consumers? }\end{array}$ \\
\hline \multirow[t]{4}{*}{$\begin{array}{l}\text { Brazilian } \\
\text { context }\end{array}$} & $\begin{array}{l}\text { How does the loss of economic access to a certain market impact the } \\
\text { acquisition of new taste regimes? }\end{array}$ \\
\hline & $\begin{array}{l}\text { How does the constant up-and-down movement in a social structure } \\
\text { operate in taste transformation process? }\end{array}$ \\
\hline & $\begin{array}{l}\text { How do consumers create strategies to adapt their tastes during the social } \\
\text { mobility process? }\end{array}$ \\
\hline & $\begin{array}{l}\text { When descending socially, how do consumers reassess previous taste } \\
\text { regimes to which they are forced to return? }\end{array}$ \\
\hline
\end{tabular}

This agenda proposes the analysis of high social mobility contexts through the lens of the Practice Theory (Schatzki, 1996; Warde, 2005), which is a main theoretical tool in taste studies (Arsel \& Bean, 2013; Maciel \& Wallendorf, 2017) due to its potential for articulating agency and structure, distinction and intentionality, and the micro and macro dimensions (Askegaard \& Linnet, 2011).

It is fundamental to perceive the structural and hierarchizing function of the social reproduction of consumption (Bourdieu, 1984) without losing sight of its systemic dimension (Schatzki, 1996; Warde, 2005), i.e. a process characterized by the formulation of the actors' strategies or improvisations when confronted with the unexpected and experiences of self-actualization, creativity and rebellion (Askegaard \& Linnet, 2011). This approach provides a profound analytical understanding of both the parameters of social life and the particularities of the culture through an analysis that tries to strike a balance between the world individuals call their own and the external world (Askegaard \& Linnet, 2011).

\section{Contributions}

The writing was mainly conducted by the first author and revised by the second author.

Revision of the text, rewriting of the text after the round of revision, reply to the reviewers, definition of the theoretical contributions was conducted by both authors.

\section{References}

Allen, D. E. (2002). Toward a theory of consumer choice as sociohistorically shaped practical experience: The fits-like-a-glove (FLAG) framework. Journal of Consumer Research, 28(4), 515532. https://doi.org/10.1086/338202

Alvesson, M., \& Sandberg, J. (2011). Generating research questions through problematization. Academy of Management Review, 36(2), 247-271. https://doi.org/10.5465/amr.2011.59330882

Appadurai, A. (1996). Modernity at large: Cultural dimensions of globalization. Minneapolis: University of Minnesota Press. 
Arnould, E. J., \& Thompson, C. J. (2005). Consumer culture theory (CCT): Twenty years of research. Journal of Consumer Research, 31(4), 868-882. https://doi.org/10.1086/426626

Arsel, Z., \& Bean, J. (2013). Taste regimes and market-mediated practice. Journal of Consumer Research, 39(5), 899-917. https://doi.org/10.1086/666595

Arsel, Z., \& Thompson, C. J. (2011). Demythologizing consumption practices: How consumers protect their field-dependent identity investments from devaluing marketplace myths. Journal of Consumer Research, 37(5), 791-806. https://doi.org/10.1086/656389

Askegaard, S., \& Linnet, J. P. (2011). Towards an epistemology of consumer culture theory: phenomenology and the context of context. Marketing Theory, 11(4), 381-411. https://doi.org/10.1177/1470593111418796

Barcelos, R. H. (2015). Gosto do consumidor: Reflexão teórica e conceptualização. RIMAR, 5(2), 3-18. Retrieved from http://eduem.uem.br/ojs/index.php/rimar/article/view/26477/16274

Barros, R., Carvalho, M., Franco, S., \& Mendonça, R. (2010). Determinantes da queda na desigualdade de renda no Brasil [Texto para discussão, TP1460]. Brasília, DF: IPEA.

Beeghley, L. (2004). The structure of social stratification in the United States. Boston: Perason, Allyn \& Bacon.

Belk, R. W. (1988). Possessions and the extended self. Journal of Consumer Research, 15(2), 139-168. https://doi.org/10.1086/209154

Belk, R. W., Wallendorf, M., Sherry, J. F., \& Holbrook, M. B. (1991). Collecting in a consumer culture. In R. W. Belk (Ed.), Highways and buyways: Naturalistic Research from the consumer behavior odyssey (pp. 178-215). Provo, UT: Association for Consumer Research.

Bloch, P. H. (1995). Seeking the ideal form: Product design and consumer response. Journal of Marketing, 59(3), 16-29. https://doi.org/10.2307/1252116

Bourdieu, P. (1984). Distinction: A Social critique of the judgment of taste. Cambridge: Harvard University.

Bourdieu, P. (2007). A distinção: A crítica social do julgamento do gosto. Cambridge: Harvard University.

Bourdieu, P., \& Wacquant, L. (1992). An invitation to reflexive sociology. Chicago: University of Chicago Press.

Carlson, L., \& Grossbart, S. (1988). Parental style and consumer socialization of children. Journal of Consumer Research, 15(1), 77-94. https://doi.org/10.1086/209147

Castilhos, R. B., Fonseca, M. J., \& Bavaresco, M. (2017). Consumption, crisis, and coping strategies of lower class families in Brazil: A sociological account. International Journal of Consumer Studies, 41(4), 379-388. https://doi.org/10.1111/ijcs.12341

Chauvel, M. A., \& Mattos, M. P. de A. Z. de (2008). Consumidores de baixa renda: Uma revisão dos achados de estudos feitos no Brasil. Cadernos Ebape.BR, 6(2), 379-388. https://doi.org/10.1590/s1679-39512008000200006

Coskuner-Balli, G., \& Thompson, C. (2013). The status costs of subordinate cultural capital: At-home fathers' collective pursuit of cultural legitimacy through capitalizing consumption practices. Journal of Consumer Research, 4O(1), 19-41. https://doi.org/10.1086/668640

Crossley, N. (2001). The social body: Habit, identity and desire. London: Sage. 
Ekström, K. M. (2006). Consumer socialization revisited. In R. W. Belk (Ed.), Research in consumer behavior (Vol. 10, pp. 71-98). Bingley: Emerald Group Publishing Limited.

Firat, A. F., \& Venkatesh, A. (1995). Liberatory post-modernism and the reenchantment of consumption. Journal of Consumer Research, 22(3), 239-267. https://doi.org/10.1086/209448

Gronow, J. (1997). The sociology of taste. New York: Routledge.

Hennion, A. (2001). Music lovers: Taste as performance. Theory, Culture \& Society, 18(5), 1-22. https://doi.org/10.1177/02632760122051940

Hennion, A. (2004). Pragmatics of taste. In M. Jacobs \& N. Hanrahan (Eds.), The Blackwell companion to the sociology of culture (pp. 131-144). Malden, MA: Blackwell Publishing Ltd

Hirschman, E. C., \& Holbrook, M. B. (1982). Hedonic consumption: Emerging concepts, methods and propositions. Journal of Marketing, 46(3), 92-101. https://doi.org/10.2307/1251707

Holbrook, M. B. (2005). The role of ordinary evaluations in the market for popular culture: Do consumers have "good taste"? Marketing Letters, 16(2), 75-86. https://doi.org/10.1007/s11002005-2774-6

Holt, D. B. (1998). Does cultural capital structure American consumption? Journal of Consumer Research, 25(1), 1-25. https://doi.org/10.1086/209523

Holt, D. B. (2002). Why do brands cause trouble? A dialectical theory of consumer culture and branding. Journal of Consumer Research, 29(1), 70-91. https://doi.org/10.1086/339922

Holt, D. B., \& Thompson, C. J. (2004). Man-of-action hero: The pursuit of heroic masculinity in everyday consumption. Journal of Consumer Research, 31(2), 425-440. https://doi.org/10.1086/422120

Ibope. (2015, setembro 10). 57\% dos brasileiros alteram hábitos de consumo ou planejamento financeiro em função $d a$ crise. Retrieved from http://www.ibope.com.br/pt$\mathrm{br} /$ noticias/Paginas/57-dos-brasileiros-alteram-habitos-de-consumo-ou-planejamento-financeiroem-funcao-da-crise.aspx

Instituto Brasileiro de Economia da Fundação Getulio Vargas. (2014). Para agência de risco Moody's, crescimento da classe média na América Latina deve desacelerar. Retrieved from http://eds.b.ebscohost.com/eds/detail/detail?vid=0\&sid=318c2661-74f3-4797-bcd9-

6ae0ae767041\%40sessionmgr102\&bdata=Jmxhbmc9cHQtYnImc210ZT11ZHMtbGl2ZQ\%3d\% $3 \mathrm{~d} \# \mathrm{AN}=\mathrm{vlex} .531894302 \& \mathrm{db}=\mathrm{edsvlx}$

Instituto Brasileiro de Geografia e Estatística. (n.d.). Pesquisa nacional por amostra de domicílios contínua - trimestral. Retrieved from

https://ww2.ibge.gov.br/home/estatistica/indicadores/trabalhoerendimento/pnad_continua/defaul t.shtm

Jannuzzi, P. de M. (2005). Indicadores para diagnóstico, monitoramento e avaliação de programas sociais no Brasil. Revista do Serviço Público, 56(2), 137-160. https://doi.org/10.21874/rsp.v56i2.222

Joy, A., \& Sherry, J. F., Jr. (2003). Speaking of art as embodied imagination: A multisensory approach to understanding aesthetic experience. Journal of Consumer Research, 30(2), 259-282. https://doi.org/10.1086/376802

Kamakura, W. A., \& Mazzon, J. A. (2013). Socioeconomic status and consumption in an emerging economy. Journal of Research in Marketing, 30(1), 4-18. https://doi.org/10.1016/j.ijresmar.2011.12.001 
Kamakura, W., \& Mazzon, J. A. (2016). Critérios de estratificação e comparação de classificadores socioeconômicos no Brasil. Revista de Administração de Empresas, 56(1), 55-70. https://doi.org/10.1590/s0034-759020160106

Kates, S. M. (2002). The protean quality of subcultural consumption: An ethnographic account of gay consumers. Journal of Consumer Research, 29(3), 383-399. https://doi.org/10.1086/344427

Kravets, O., \& Sandick, O. (2014). Competently ordinary: New middle class consumers in the emergent markers. Journal of Marketing, 78(4), 125-140. https://doi.org/10.1509/jm.12.0190

Maciel, A. F., \& Wallendorf, M. (2017). Taste engineering: An extended consumer model of cultural competence constitution. Journal of Consumer Research, 43(5), 726-746. https://doi.org/10.1093/jcr/ucw054

MacInnis, D. J. (2011). A framework for conceptual contributions in marketing. Journal of Marketing, 75(4), 136-154. https://doi.org/10.1509/jmkg.75.4.136

Magaudda, P. (2011). When materiality 'bites back': Digital music consumption practices in the age of dematerialization. Journal of Consumer Culture, 11(1), 15-36. https://doi.org/10.1177/1469540510390499

Mattar, F. (1997, October). Novo modelo de estratificação socioeconômica para marketing e pesquisas de marketing. Proceedings of Seminários em Administração, São Paulo, SP, Brazil, 2.

Mattoso, C. (2013, abril). A posição social, sua influência no consumo da base da pirâmide e a adoção de um novo modelo de estratificação social. Revista Brasileira de Pesquisas de Marketing, $\begin{array}{llllll}\text { Opinião } & e & \text { Mídia, } & \text { 12, 45-58. } & \text { Retrieved }\end{array}$ http://www.revistapmkt.com.br/Portals/9/Edicoes/PMKT_Ciencia_012_04.pdf

McCracken, G. (1986). Culture and consumption: A theoretical account of the structure and movement of the cultural meaning of consumer goods. Journal of Consumer Research, 13(1), 71-84. https://doi.org/10.1086/209048

McQuarrie, E. F., Miller, J., \& Phillips, B. J. (2013). The megaphone effect: Taste and audience in fashion blogging. Journal of Consumer Research, 40(1), 136-158. https://doi.org/10.1086/669042

Mills, C. W. (1951). White collar: The American middle classes. Oxford, UK: Oxford University Press.

Misoczky, M. C. A. (2003). Implicações do uso das formulações sobre campo de poder e ação de Bourdieu nos estudos organizacionais [Special Issue]. Revista de Administração Contemporânea, 7, 9-30. https://doi.org/10.1590/s1415-65552003000500002

Moreira, C., Casotti, L., \& Campos, R. (2018). Socialização do consumidor na vida adulta: Desafios e caminhos para a pesquisa. Cadernos Ebape.BR, 16(1), 119-134. http://dx.doi.org/10.1590/1679395157008

Neri, M. (2010). A nova classe média: O lado brilhante da pobreza. Rio de Janeiro: FGV-IBRE, CPS.

Pereira, S. J. N., \& Ayrosa, E. A. T. (2012). Between two worlds: An ethnographic study of gay consumer culture in Rio de Janeiro. Brazilian. Administration Review, 9(2), 211-228. Retrievved from http://www.scielo.br/pdf/bar/v9n2/a06v9n2.pdf. http://dx.doi.org/10.1590/S180776922012000200006

Pignata, F. A., \& Carvalho, D. O. de (2015). Efeitos da crise econômica no Brasil em 2015. Revista Eletrônica Diálogos Acadêmicos, 9(2), 4-18. Retrieved from http://www.semar.edu.br/revista/downloads/edicao9/1-artigo.pdf 
Ponte, L. F., \& Mattoso, C. Q. (2014). Capital cultural e o consumo de produtos culturais: As estratégias de consumo de status entre mulheres da nova classe média. Revista Brasileira de Marketing, 13(6), 18-33. https://doi.org/10.5585/remark.v13i6.2613

Quintão, R., Brito, E., \& Belk, R. (2015, September). The taste transformation ritual and connoisseurship consumption. Proceedings of the Encontro Nacional da Associação Nacional de Pós-Graduação e Pesquisa em Administração, São Paulo, SP, Brazil, 39.

Reckwitz, A. (2002). Toward a theory of social practices: A development in culturalist theorizing. European Journal of Social Theory, 5(2), 243-263. https://doi.org/10.1177/13684310222225432

Rocha, A. R. C., Rocha, A. da, \& Rocha, E. (2016). Classifying and classified: An interpretive study of the consumption of cruises by the "new" Brazilian middle class. International Business Review, 25(3), 1-9. https://doi.org/10.1016/j.ibusrev.2015.02.006

Rook, D. W. (1985). The ritual dimension of consumer behavior. Journal of Consumer Research, 12(3), 251-264. https://doi.org/10.1086/208514

Sandikci, O., \& Ger, G. (2010). Veiling in style: How does a stigmatized practice become fashionable? Journal of Consumer Research, 37(1), 15-36. https://doi.org/10.1086/649910

Scalon, C., \& Salata, A. (2012). Uma nova classe média no Brasil da última década? O debate a partir da perspectiva sociológica. Revista Sociedade e Estado, 27(2), 397-407. https://doi.org/10.1590/s0102-69922012000200009

Schatzki, T. (1996). Social practices: A Wittgensteinian approach to human activity and the social. Cambridge, UK: Cambridge University Press.

Schouten. J. W. (1991). Selves in transition: Symbolic consumption in personal rites of passage and identity reconstruction. Journal of Consumer Research, 17(4), 412-25. https://doi.org/10.1086/208567

Schouten, J. W., \& McAlexander, J. (1995). Subcultures of consumption: An ethnography of the new bikers. Journal of Consumer Research, 22(1), 43-61. https://doi.org/10.1086/209434

Sherry, J. F., Jr. (1983). Gift giving in anthropological perspective. Journal of Consumer Research, 10(2), 157-168. https://doi.org/10.1086/208956

Shove, E. (2003). Comfort, cleanliness and convenience: The social organization of normality. New York: Berg.

Skandalis, A., Banister, A., \& Byron, J. (2015). Toward a spatial theory of taste formation. Advances in Consumer Research, 43, 404-408. Retrieved from http://www.acrwebsite.org/volumes/v43/acr_vol43_1019770.pdf

Thompson, C. J., \& Hirschman, E. C. (1995). Understanding the socialized body: A poststructuralist analysis of consumers' self-conceptions, body images and self-care practices. Journal of Consumer Research, 22(2), 139-153. https://doi.org/10.1086/209441

Ulver, S., \& Ostberg, J. (2014). Moving up, down or sideways? Exploring consumer experience of identity and status incongruence. European Journal of Marketing, 48(6), 833-853. https://doi.org/10.1108/ejm-07-2012-0418

Üstüner, T., \& Holt, D. B. (2010). Toward a theory of status consumption in less industrialized countries. Journal of Consumer Research, 37(1), 37-56. https://doi.org/10.1086/649759 
Üstüner, T., \& Thompson, C. J. (2012). How marketplace performances produce interdependent status games and contested forms of symbolic capital. Journal of Consumer Research, 38(5), 796-814. https://doi.org/10.1086/660815

Venkatesh, A., Joy, A., Sherry, J. F., Jr., \& Deschenes, J. (2010). The aesthetics of luxury fashion, body and identify formation. Journal of Consumer Psychology, 20(4), 459-470. https://doi.org/10.1016/j.jcps.2010.06.011

Warde, A. (1997). Consumption, food, and taste: Culinary antinomies and commodity culture. London: Sage.

Warde, A. (2005). Consumption and theories of practice. Journal of Consumer Culture, 5(2), 131-153. https://doi.org/10.1177/1469540505053090

Woodward, I., \& Emmison, M. (2001). From aesthetic principles to collective sentiments: The logics of everyday judgments of taste. Poetics, 29(6), 295-316. https://doi.org/10.1016/s0304$422 \times(00) 00035-8$

Zeithaml, V. A. (1988). Consumer perceptions of price, quality, and value: A means-end model and synthesis of evidence. The Journal of Marketing, 52(3), 2-22. https://doi.org/10.2307/1251446

\section{Authors' Profiles}

Lucivania Filomeno Ponte

Av. Joaquim da Costa Lima, s/n, São Bernardo, 26165-225, Belfort Roxo, RJ, Brazil. E-mail address: lucivania.ponte@ifrj.edu.br. https://orcid.org/0000-0001-9641-6403

Roberta Dias Campos

Rua Pascoal Lemme, 355, Ilha do Fundão, Cidade Universitária, 21941-918, Rio de Janeiro, RJ, Brazil. E-mail address: roberta.campos@coppead.ufrj.br. https://orcid.org/0000-0002-7091-7901 